\title{
WOMEN'S EXPERIENCES OF REPORTING RAPE TO THE POLICE: A QUALITATIVE STUDY
}

\section{Nina du Plessis, Ashraf Kagee, Anastasia Maw}

\section{INTRODUCTION}

South Africa has the highest incidence of rape in the world among the countries that report reliable crime statistics (Snyman, 2005). Between April 2006 and March 2007, 52617 rapes were reported to the police in South Africa ("Information management, South African Police Services", n.d.). A national crime survey conducted by Statistics South Africa (SSA) found that one out of two rape survivors reported the matter to the police (SSA, 2000), while a threeprovince survey by the Medical Research Council on violence against women found that only one in nine victims reported their rape experience (Jewkes, Penn-Kekana, Levin, Ratsaka \& Schrieber, 2001).

As the police officer represents the survivor's initial contact with the law enforcement system, the manner in which he or she engages with the survivor is likely to have an effect on the individual's psychological and emotional wellbeing and may influence the survivor's perception of the system (Temkin, 1997). An unsupportive response from police personnel may have a detrimental effect on adaptation to, and recovery from, the trauma of rape (Burgess \& Holmstrom, 1978). In the immediate aftermath of trauma a sympathetic presence and assurances of safety and protection are important for the survivor (Herman, 1992). The internalisation of misconceptions about sexual violence among the police and the expression thereof in the statement-taking context may then have disastrous effects on a survivor (Ward, 1995).

The fact that women are unwilling to report rape to the police has been well documented (Walklate, 1995). Indeed, the poor treatment of survivors of sexual violence is seen to be a consequence of underlying misconceptions about rape and society's prejudicial attitudes towards women (Ward, 1995). Burt (1980) defined rape myths as the stereotyped way in which people view rape, rapists and rape victims. In communities where there is a high level of acceptance of rape myths, there is also a higher level of rape (Burt \& Albin, 2006; Chiroro, Bohner, Viki \& Jarvis, 2004). A substantial contributing factor to the underreporting of rape can be attributed to the widespread existence of rape myths, one of which is that women fabricate rape accusations out of malice, guilt and revenge (Madigan \& Gamble, 1991). These findings have implications for the survivors' process of meaning making and hence recovery (Lira, Koss \& Russo, 1999). Furthermore, women have been found to have internalised rape myths, resulting in a tendency to blame themselves for the rape; the acceptance of rape myths thus contributes to the underreporting of rape and prevents survivors from acknowledging their experiences (Koss \& Harvey, 1991). It has also been suggested that the acceptance of rape myths within a society contributes to what has come to be known as 'secondary victimisation' of survivors of rape, that is the disparagement and alienation of the survivor when she turns to others for help and support (Madigan \& Gamble, 1991).

If a woman does report a rape, the police officer is the first representative of the criminal justice system the reporting survivor encounters. The quality of her contact with the police officer may shape her perception of the entire prosecution process (Jordan, 2002). According to the SAPS website, a rape survivor may expect the following when reporting a rape to the police ("Sexual Offences, South African Police Services" n.d.): 
- She may have a family member or friend present while giving her statement;

- She may make adjustments to or change her original statement;

- She may make her statement in her own language;

- She has the right to a copy of her statement and a case number;

- She has the right to medical care, if necessary; and

- She will be notified by the investigating officer should of any developments in her case such as the suspect being released on bail or if the suspect is arrested, as well as the outcome of the case.

Successful handling of rape cases by police also contributes to the survivors' perception of a just world, and may help to restore the survivor's sense of mastery and control. Good policesurvivor relations have been shown to lead to better survivor adjustment (Brown, 1970, cited in Ward, 1995).

\section{Barriers to reporting rape}

A three-province study conducted by the Medical Research Council found that only $15 \%$ of women who had experienced being forced to have sex against their will reported the event to the police. The survey also found that having no education was a major barrier to contacting the police. Young women were more likely to report rape to the police than older women (Jewkes et al., 2001).

The fact that the frequency of rape reported in community-based surveys is considerably higher than the number of rapes reported to the police suggests that there are barriers to reporting (Christofides, Webster, Jewkes, Penn-Kekana, Marten, Abrahams \& Kim, 2003). These barriers include fear of further trauma, fear of not being believed, fear of retaliation by the perpetrator, lack of physical access to the police and believing that reporting would not lead to the arrest of the perpetrator (Christofides et al., 2003). Research has also shown that women are less likely to report rape if the rapist is an acquaintance or relative (Pino \& Meier, 1999). In many cases, where the victim knows the perpetrator, she may fear intimidation and threats to her safety if charges are laid (Pretorius \& Louw, 2005). The relationship between the victim and the offender appears to be an important factor influencing the decision to report and the police response to the victim (Williams, 1984). Violence by known offenders is much less likely to come to the attention of the authorities than violence by strangers (Gartner \& MacMillan, 1995). Pino and Meier (1999) found that acts of rape are almost twice as likely to be reported if the perpetrator is a stranger, and nearly 5 times more likely if something is stolen from the victim. The odds of reporting also increase if any injuries were sustained or if the victim required medical attention (Pino \& Meier, 1999). In addition, the likelihood is higher that women will receive sympathetic police responses when attacked by strangers and when sustaining severe physical injuries (Jordan, 2001).

\section{Research on reporting rape in South Africa}

Stanton, Lochrenberg and Mukasa (1997) conducted a study to assess the Wynberg Sexual Offences Court model (WSOC) in Cape Town, South Africa, and found that the majority of their sample of 13 women expressed dissatisfaction with the services they received from the police. Seven women from the sample reported that the police contributed directly to making the process of reporting traumatic, especially by being made to repeatedly state what had happened to them and having to give multiple statements. The majority of the sample stated 
that they felt blamed and exposed to prejudicial attitudes and that the police displayed a lack of sympathy and interest (Stanton et al., 1997).

More recently, Combrinck and Skepu (2003) conducted a study examining rape survivor's experiences of the criminal justice system, with a specific focus on the issue of bail. They found that survivors and counsellors reported major difficulties in establishing and maintaining contact with investigating officers (IOs). There had also been reports of encouraging the survivor to drop the case and failing to provide her with necessary information (Combrinck \& Skepu, 2003). The impact on the survivors was clearly negative and resulted in a breakdown of trust and confidence. Positive experiences, on the other hand, were linked to the expectation that the perpetrator(s) would be arrested and success in maintaining contact with the IO (Combrinck \& Skepu, 2003). Providing information to the survivor not only contributes to her peace of mind, psychological recovery and satisfaction with the police, but is also a prerequisite for access to other services such as counselling and legal advice (Pretorius \& Louw, 2005).

It is evident that attitudes of police personnel about rape and women influence their assessment of a case as founded or unfounded. The police are pivotal in their ability to influence which offences are recorded, investigated and passed through the court system (Jordan, 2002). The encounter with the police may have a psychological impact on survivors and women's efforts to regain power and autonomy may either be enhanced or undermined by the police response (Jordan, 2001). The present study sought to explore the experiences of a group of historically disadvantaged women who reported rape to the police.

\section{METHOD}

The study was conducted at a care centre in a public hospital located on the Cape Flats. Thuthuzela care centre is a joint project run by the National Prosecuting Authority, the Department of Health, the SAPS and various NGOs. It provides rape survivors with medical treatment, forensic examination, counselling and advice on how to proceed with their legal case against the perpetrator.

\section{Participants}

A total of 21 women were approached to take part in the study. Of these, two declined to be involved. Convenience sampling was used to recruit participants, which entailed interviewing the first 16 women who were available and who were willing to take part in the study. Of the 19 women who agreed to participate, three did not arrive for interviews, yielding a total of 16 interviews. The women's ages ranged from 17 to $49(\mathrm{M}=27)$. In the case of the 17-year-old participant, informed consent was obtained from both her and her parents. Fourteen of the participants were African and two were Coloured. ${ }^{1}$ The participants' levels of education ranged from Grade 5 to tertiary level. All participants resided in areas on the Cape Flats served by the care centre. Nine of the women were unemployed and seven were employed. Eight of the women were single and nine were partnered; none of the participants was married. All rapes were reported on the date they occurred or within 24 hours of happening. The earliest reported rape occurred in August 2003 and the most recent case reported was on the 29 October 2006.

\footnotetext{
${ }^{1}$ While we recognise that all racially constructed terms are offensive, we refer to them in this paper because they are relevant to the South African context: these racial classifications employed during the apartheid regime were linked to differential levels of access to resources. The legacy of this inequitable access remains today. In this article we use the terms Coloured and African since these are commonly used terms in South Africa today and were used by the participants themselves in this study when describing themselves or others.
} 
The interviews took place an average of 99 days after the rape had occurred, ranging from four days later in one case, to three years later in another.

\section{Procedure}

The women were initially approached by a nurse or counsellor and asked if they would be willing to speak to a researcher. Upon their agreement, informed consent was obtained and a time that suited the participant was arranged to conduct the interview.

All interviews took place in a private and comfortable room. Seven of the interviews took place in the presence of a third person who served as a translator/co- researcher. All interviews were transcribed, translated and back translated where necessary. In the case of the back translation, a translator's services where contracted to back translate three interviews where there was dialogue in Xhosa. In the case of Afrikaans text, the interviews were translated and transcribed with the assistance of an Afrikaans-speaking co-researcher who speaks the same dialect of Afrikaans that is spoken on the Cape Flats. Both co-researchers had also completed the Rape Crisis counselling training course and were experienced in working with survivors of rape.

\section{Data collection}

Qualitative semi-structured interviews were conducted to elicit from respondents their ideas, opinions and feelings about the process of reporting rape to the police. The emphasis of the interview schedule was on the women's perception of events from the point at which the incident was first reported to the police. Women were asked about each stage of the reporting process including initial contact, statement taking, police response and case progress (Jordan, 2001). The interview schedule was structured around the following areas of content, informed by the literature: demographic information, assault variables, initial contact with the police, statement taking, case progress and follow-up, and general attitude towards reporting.

\section{Data analysis}

The interviews were recorded on a digital recorder and, once each interview was completed, the audiotapes were transcribed and analysed. A thematic analysis was conducted in the stages outlined by Strauss and Corbin (1990). This involved open coding where labels were generated to describe themes in the data on both a detailed and abstract level (Pidgeon \& Henwood, 1997). In order to collapse these codes into a manageable size, they were then grouped into clusters based on differences and similarities. Each cluster was then labelled, fully described and coded for its range and variations. Data were then reworked and categories were adjusted (Swanson, 1986). Codes and categories were sorted, compared and contrasted until saturated, that is, until the analysis produced no new categories or codes.

\section{RESULTS}

The four broad themes that emerged from the data were: (i) decision to report; (ii) reporting, police reaction and procedure; (iii) police follow-up; and (iv) general attitude towards the reporting.

\section{Decision to report}

After the rape five survivors reported that their primary concern was to access medical attention. With regards to making contact with the police, in six cases the police were called to the women's homes and in ten cases women went to the police station to report. In 12 cases the women said that it was their own decision to report the rape and in four cases others had notified the police on their behalf. 


\section{Relationship to the perpetrator}

The survivor's relationship to the perpetrator reportedly influenced the women's decision to report the rape in eight of the cases. In nine cases the perpetrator was unknown to the survivor and in seven cases the complainant reportedly knew the perpetrator. In the following quote Emma (38), who was abducted and raped by an unknown man in his flat, explained that rape is unpleasant even if one is involved in an intimate relationship with the perpetrator. When asked how she came about the decision to report the rape she said:

Because I didn't like it. No one will like it if you raped by someone you don't even know, even if it's your boyfriend. How can you live like that?

Participants 6 and 10 said they thought that going to the police would be futile because they did not know the perpetrators who raped them and therefore the police would not investigate the case. Penny (38) was raped by an unknown man in her home. She said:

I didn't want to go to the police but one of my neighbours say I must go, and I say I know the police, when I say I don't know this man they are not going to follow this case...

Whether or not the women knew the perpetrators influenced their perception of what to expect in terms of police service delivery in their rape cases, as is evidenced from the quotation above.

\section{Medical attention}

In five cases wanting medical attention was the reason that participants reported their rape to the police. Lisa (25), who was raped by three unknown perpetrators in an open field, explained that she first presented at Mitchell's Plain hospital, where she was told she had to report to the police station before receiving medical attention. Patty (25), who was raped by three perpetrators, one who was known to her, and Brenda (28), who was raped by three unknown perpetrators, reported that their first priority was to access to medical care.

TABLE 1

DETAILS OF REPORTING AND ARRESTS

\begin{tabular}{|l|c|c|c|c|c|c|}
\hline Participant no. & $\begin{array}{c}\text { Read/check } \\
\text { ed stmt }\end{array}$ & $\begin{array}{c}\text { Copy of } \\
\text { stmt }\end{array}$ & $\begin{array}{c}\text { Gender of } \\
\text { PO }\end{array}$ & $\begin{array}{c}\text { Comfortable } \\
\text { lang. }\end{array}$ & Case no. & Perp. A/NA \\
\hline 1 & No & No & F & Yes & Yes & NA \\
\hline 2 & No & No & M & Yes & Yes & A \\
\hline 3 & No & No & M & Yes & Yes & NA \\
\hline 4 & Yes & No & F & Yes & Yes & NA \\
\hline 5 & No & No & F & Yes & No & NA \\
\hline 6 & No & No & F & Yes & No & NA \\
\hline 7 & Yes & No & F & Yes & Yes & A \\
\hline 8 & No & No & F & No & Yes & NA \\
\hline 9 & No & No & F & Yes & Yes & A \\
\hline 10 & No & No & F & Yes & Yes & NA \\
\hline 11 & Yes & No & F & Yes & Yes & NA \\
\hline 12 & No & No & F & Yes & No & NA \\
\hline 13 & No & No & F & Yes & Yes & NA \\
\hline 14 & No & No & F & Yes & Yes & A \\
\hline 15 & No & No & M & Yes & No & NA \\
\hline 16 & No & No & M and $F$ & Yes & Yes & NA \\
\hline
\end{tabular}

Note: $\mathrm{M}=$ male; $\mathrm{F}=$ female; $\mathrm{NA}=$ not arrested; $\mathrm{A}=$ arrested; stmt=statement; $\mathrm{PO}=$ police officer taking statement. 


\section{Reporting, police reaction and procedure}

Table 1 summarises the experiences of reporting based on the reporting protocol on the SAPS website. Notably, no women received copies of their statements and only three women were offered the opportunity to read or check their statements. The police stations where each woman reported are listed in order to show that in all but one case the women reported to the nearest police station to their area of residence. All women except one made their statements in a language in which they were comfortable. Four of the perpetrators had been arrested at the time the interviews took place.

\section{Police prioritisation}

In three cases police obtained statements from the survivors before attending to their medical needs. Andrea (22), who was abducted and raped by an unknown man in an open area, explained that she had to wait for the police to take statements from others around her and return to the scene of the rape before she received medical attention for a gunshot wound in her buttocks. She expressed her frustration at the fact that the police did not acknowledge that she was shot. Once Andrea arrived at the hospital, the officer assigned to her case went off duty and as a result she was left at the hospital and had to make her own way back to the police station in order to give further statements. According to police protocol, police are to see that survivors receive medical attention and are then transported back to the police station in order to complete statements.

Patty (25) was raped by two unknown men in her home, had been stabbed with a knife during the attack and said that the police took her statement before taking her to the clinic, despite her being in pain. In two of the cases described above, it seems that women's desire to receive medical attention was overshadowed by police procedure and protocol.

\section{Waiting time}

Once survivors arrived at the police station, they reported waiting from between 1 and 5 hours in order to give their statements. All women except one gave their statements in the victim support room, which is intended to provide privacy and make the survivor feel safe in order to give as accurate a statement as possible. Emma (25) and Naomi (17) explained that they had to wait for the police to attend to the other people who had arrived at the police station before them. Penny (38) recalled that she waited for more than 4 hours to make her statement at the police station, as she had arrived there before $8 \mathrm{am}$ in the morning. The police told her that she had to wait for the Family Violence Sexual Offences and Child Protection unit (FCS) to arrive before she could give her statement. Participant 8 was told that she had to wait for an ambulance to transport her to the clinic from the police station, which also resulted in a long waiting period. Three of the participants indicated that they expected to wait substantial periods of time, but 11 of the women reported that the waiting times were physically and emotionally draining.

\section{Police insensitivity and disorganisation}

In the current study four women report that they experienced police questioning to be irrelevant, judgmental and repetitive. Naomi, a 17-year-old student, explained how she had to repeat herself while giving her statement and how she felt judged by a policewoman's comments and questions:

She was like asking other questions that had nothing to do with what happened relating to me and him. Like um, she asked me "how do I know him?" and then I told her and she 
asked me if I went out with him and I said yes, and then she was like "oh and then?" as if like how stupid kind of thing so ja...

Lisa (25) said that she felt that a question about why she was out late at night from a policewoman was unnecessary and insensitive. In addition, the policewoman reportedly accused the participant of being drunk. Participant 1 talked about the difficulty she had with the repetitive questioning while giving her statement. The following quote illustrates the problems with recall that survivors of rape sometimes experience, particularly if they are trying to verbalise what has happened to them shortly after it has occurred:

Emma: I didn't feel comfortable you know mos [like] when these people they ask a lot of questions and they repeat one question all the time. Sometimes you don't remember, sometimes you forget also you know... a lot of questions.

Debbie (20), who was abducted and raped by three perpetrators, reportedly experienced disorganisation on the part of the police when she arrived to report her case. In the quote below she describes being referred to a number of different officers and the difficulty she experienced when trying to give her statement:

I came to the police station um, I was sent from one person to the next um, I had to explain myself over and over and then they um... I was sitting there for more than three hours waiting for somebody to take to me to Jooste and um the lady that took my statement never finished it um because they were eating, walking in and out um talking...

Insensitive and disorganised statement-taking procedures on the part of the police made some participants feel judged, and the procedures were unhelpful to both the women reporting.

\section{Police follow-up}

In 15 cases participants felt responsible for their own cases once they had given their statements to the police. In all but three cases the participants had not received any follow-up information or contact from the police about their cases, and even though they wanted to proceed with their cases, the women were not sure how to go about it. The participants wanted to take action and were frustrated with the slowness of the criminal justice system.

\section{Police failure to respond to complainants' concerns}

In the six cases in which incidents of intimidation and threats from the perpetrators were reported to the police, three were apparently brushed aside and the women were told to report back if the intimidation recurred, or they were simply turned away. In the case of Naomi, she explained that both her parents tried to inform the police that the perpetrator was intimidating her, but they received no response from the police officers in charge of her case. Debbie (20) tried to alert the police to the whereabouts of the perpetrators who were intimidating her, only to be told that the police had a shortage of vehicles every time she called them. She had therefore not been able to leave her house for two weeks after the rape.

Lisa (25) reported that she was in possession of information that may have lead to the arrest of the perpetrators in her case. However, when she contacted the investigating officer, she was told that he was not interested in the information because it was incomplete. The police reportedly told Linda, a 21-year-old complainant who was raped by two unknown men, that she didn't have a case, because she did not know the perpetrators and there were no witnesses. When she approached the investigating officer with additional information, she was told that because she had failed to mention this information when she gave her statement and she had "withdrawn" the case, as advised by the police, she could not reopen it. 


\section{Wanting case information}

All the participants expressed the need to receive information about the status of their cases and a desire to continue with their cases. Three survivors reported knowing who the investigating officer was in their cases, and 13 did not know and had not received any further correspondence since reporting the rape. If women did know who the investigating officer in their case was, it was difficult to get into contact with the officer and even more difficult to get any information. The need to be kept updated with case information by the police was expressed particularly in the 12 cases where the perpetrator had not been arrested. It appeared that not knowing the status of one's case made participants feel powerless and frustrated.

\section{Receiving incorrect information}

According to what the survivors reported in the research interviews, individual officers misinformed three women when they contacted the police with questions and the information they were given was simply untrue. Kate, a 30-year-old complainant who was raped in a car by an unknown man, was told that the police had released the perpetrator in her case, once he was charged and arrested, because they could only hold the man for 45 hours. He had not paid bail. Lisa, a resident of one Cape Flats township, was told by a female officer that people from the her area could not use the police station located in the adjacent township as it was not the correct police station to report at. Finally, Linda (21), raped by two unknown perpetrators, described feeling shocked and powerless when the police told her that she could not lay a charge of rape because she did not know the perpetrators.

Although five women reported that they felt believed and treated with empathy by the police, four women did not know their case numbers, and in 13 cases did not know who their investigating officers were, or how to contact the investigating officer. In only four cases were the perpetrators arrested, and of those, only one perpetrator had been sentenced and incarcerated at the time of the interviews.

\section{General attitude towards the reporting}

\section{Unsatisfactory service}

In ten cases the participants' attitudes towards the service they received from the police were overtly negative. The women who openly complained about the police did so only towards the second half of the interviews, although this may be a result of the structure of the interview schedule. Those who felt that they had received all they could from the police seemed to have low expectations to begin with. When asked if she would advise other women to report rape to the police, Andrea (22), who was raped by an unknown perpetrator and shot in the rear, stated that reporting her rape was treated with the same concern by the police as reporting a stolen phone. Naomi (17) felt that the police were simply not doing their jobs at the police station where she reported her rape. In the following quote she describes the bad service that she experienced:

I don't think they are doing their job because um you can go there and lay a charge and for me it's almost like they are going to tell you that your docket is lost or something, because people are sitting there for hours and they are doing nothing, because they walking in and out, going to their friends, talking, and having lunchtime before it is their lunchtime and stuff like that...

Bernice (32) was raped in 2003 by her boyfriend at the time and he had evaded incarceration for over three years. She described how her perception of the police changed from thinking she 
would receive help and support to believing that the police simply do not care about people, based on her experiences at the police station. Lisa, a 25-year-old nurse, summarised the attitude that it is most likely that the police would not take action and, if they did, the perpetrators would be back in the community, as they probably would not get convicted. Lisa stated:

Most of the people they advise me to not to go to the police if I can find information, not to go to the police because there is nothing they are going to do. Yes they are going to do something but after a month those guys are gonna come and kill me so it's a risk.

What this means for the survivor is that, when reporting rape to the police, there is a risk that the perpetrator will seek her out if he is not convicted or is let out on bail.

The data provided by the participants illustrate the unpleasant experience of reporting a rape to the police. The trauma was still relatively fresh for 15 of the 16 participants at the time when the interviews were conducted and survivors were only at the beginning of the process of trying to make meaning out of what had happened to them. The lack of prompt medical attention and long waiting periods in crowded waiting rooms did not serve to make the process physically or emotionally comfortable. At least 10 survivors reportedly experienced judgmental attitudes from the police, and overall the police were unable to provide survivors with case information and follow-up or, in three cases, to protect them from intimidation after the rape.

\section{DISCUSSION}

\section{Relationship to the perpetrator}

The issue of the relationship to the perpetrator is a complex one. Previous research suggests that women are less likely to report the rape if the perpetrator is known to the survivor as they may fear retaliation and threats to their safety if the charges are pursued (Madigan \& Gamble, 1991; Pino \& Meier, 1999). Similarly, it has been found that women are twice as likely to report the rape if the perpetrator is a stranger and that police are then more likely to respond sympathetically (Jordan, 2001). Seven of the participants knew the perpetrators, while nine women did not. Two women made reference to the fact that the perpetrators were not their boyfriends and being in a relationship with someone seemed to somehow lessen the seriousness of the rape. Two other women believed that not knowing the perpetrator meant that the police would not investigate the case. In one case the police told a participant that she could not lay a charge because she did not know the perpetrators. Another woman had such little faith in the police that she explained that, if she knew who her rapist was, she would not have reported the case as she would rather have taken justice into her own hands. The influence of the victimperpetrator relationship on reporting, then, mostly contradicts what has been found in past studies (Gartner \& MacMillan, 1995; Madigan \& Gamble, 1991; Williams, 1984). The participants who knew their perpetrators described the rape in a way that sought to lessen the seriousness of the offence if the participant was in an intimate relationship with the perpetrator. At least three survivors made reference to the perpetrator not being their partner or boyfriend as part of their narrative about being raped, confirming the seriousness of the rape to the interviewer. By doing so, they indicated their acceptance of the assumptions of the traditional heterosexual relationship. Seen from another perspective, the "male sexual drive discourse" described by Holloway (1984, cited in Gavey, 2005) holds that the uncontrollable need to have sex is part of the make-up of normal, healthy men. The participants thus demonstrated the internalisation of the cultural truth that, if they were in a relationship with a man, he is entitled to sexual intercourse from his partner because he has no control over his sexual needs. 


\section{Medical attention and access issues}

The fact that five survivors sought out medical attention following the rape mirrors the finding that the odds of reporting are increased if any injuries were sustained or if the survivor required medical attention (Pino \& Meier, 1999). The centre provides women with medication to prevent the transmission of sexually transmitted infections, and also provides anti-retroviral medication to prevent the transmission of HIV. It was found that in the five cases when police came to collect participants, they were fairly timely, but one woman phoned the police only to receive no answer and therefore had to walk to the police station herself. Access to the police station was an issue of concern for the participants. In 10 cases survivors made their own way to the police station either because of lack of transport money or access to a telephone. Five participants were collected by the police and in one case; the participant was driven to the police station by her family. The remaining 10 survivors made their way to the police station by public transport or on foot. Access to police stations has been found to be a barrier to reporting rape in rural areas (Artz, 1999). It is arguable that for this sample of women access to a police station was less of a barrier because the women live in an urban setting; however, 10 women still encountered problems in making contact with the police because of lack of transport (their own or the police's) and lack of access to telephones, resulting in 10 women having to find their own way to the nearest police station.

\section{The role of the police}

A decision by police to take statements before ensuring that the survivors received medical attention was reported by three participants, one of whom had a gunshot wound and the other a stab wound. This is a worrying finding and suggests that the police's focus on their own procedures may indeed obscure their appreciation of how these procedures may impact upon the victim (Jordan, 2001). In one case a participant was left at the hospital and told to make her own way to the police station because the officer on duty's shift had ended. While such treatment indicates negligence and is similar to the findings of the study on the WSOC conducted by Stanton et al. (1997), it also has to do with the nature of police work and organisational problems that arise while doing shift work (Rasool, Vermaak, Pharoah, Louw \& Stavrou, 2003).

Long waiting periods were a concern reported by 10 women in the current study. No women were giving copies of their statements and none seemed to be informed of their rights to have a support person present. In terms of what is promised on the SAPS website, the police performed poorly. Judgmental or repetitive questioning by the police experienced by one third of the sample supports the findings of the Department of Health survey cited above. Although these questions may be argued to be relevant, they were experienced as distressing by the survivors.

The three women who stated that they had been drinking or drugging at the time of the rape did so as if they perceived that this cast great doubt on their story. Police attitudes to this kind of behaviour reportedly included knowing looks, lectures and even refusing to investigate the case in one situation. The greater likelihood of the police to attribute blame to survivors if they had been drinking or drugging is in agreement with the findings of Ward (1995).

The low level of arrests in this sample, and therefore arguably potential convictions, found in the participant's rape cases is not surprising and in keeping with the literature documenting low conviction rates in rape cases (Smythe, 2004; Temkin, 1999; Vetton, 1999). Questioning and disbelieving attitudes and lack of arrests by the police could lead to the internalisation or 
confirmation of rape myths and a decreased sense of self-worth for the survivors. Not only can this lead to an increase of distrust in the police, but also a sense that nobody cares and recognises the seriousness of the experience of rape.

\section{Case progress}

In terms of case progress, the findings of the present study mirror those of Combrinck and Skepu (2003). Examples include lack of interest in investigating the case; recommending victims drop the case; and failing to obtain information from the victim. Participants' needs to have access to information and to be kept informed about their case's progress were not met. Participants had heard from their investigating officer in three cases, and 13 did not know who the relevant officer was. Participants consistently expressed the desire to be kept informed about the developments of their case, but were almost never informed when the perpetrator was let out on bail or could not be found. The desire to be kept informed of case progress and the inability of the police to provide consistent updates was similarly reported by Stanton et al. (1997). The responsibility of obtaining information about the case then became solely the participants', and even so, their efforts were mostly futile.

The rape myth that women deserve or ask for rape and that rape only happens to certain kinds of women has been described by feminist scholars such as Koss, Heise and Russo (1994) and Burt (1980). The prevalence of, and adherence to, rape myths became apparent within both male and female police officer's treatment and questioning of rape survivors. In this way the impact of the rape was minimised and undermined. In terms of female police officers, it has been suggested that minimising the impact of rape and adopting a judgmental attitude towards participants serves as a method of distancing them from the survivors (Brems \& Wagner, 1994). For this reason unsympathetic and ostracising treatment of rape survivors by female officers is not an uncommon occurrence (Brems \& Wagner, 1994). Stephanus (2006) found that police officials hold negative views about women, which impacts on their perceptions of rape victims. Stephanus therefore questions whether female police officers are indeed more suitable to deal with rape victims, or whether males and females are equally able to deal with sexual offences (2006).

Variables such as being under the influence of alcohol and drugs at the time of the rape, relationship to the perpetrator and extent of physical injury were all issues that the police focused on in order to prove that rape survivors were in some way responsible for their own rape. Several rape myths, including that women lie or fabricate stories of rape, women ask for it, or that certain types of women deserve to be raped (Burt, 1980; Koss et al., 1994; Ward, 1995) underlie the police's suspicious questioning of the participants around the abovementioned circumstances surrounding the rape. The participants themselves may have been aware of these myths and believed that the myths informed the manner in which the police responded to their respective complaints of rape.

Seen from within patriarchal discourse, rape is an act of sexual objectification. Behaviours such as drinking or drugging, dressing seductively and being out late at night are understood as provoking rape. Being raped often lessens a women's value in both her own eyes and those of society, and she is perceived as damaged. The reactions of male relatives and partners to rape in the present study suggested the need to avenge the damage to their property because it had been dirtied and devalued. Within the act of rape and the avenging of rape, women are objects, belonging either to the perpetrators or the protectors. The trauma women experience as a result 
of rape is informed by this stigmatisation and in order to be treated with sympathy, women either deny or minimise the impact of rape, or attempt to prove that they were innocent victims.

Feminist scholarship challenges the supposed natural discourses of sexuality and argues that gender identities should be viewed to be in a state of constant flux and lacking a fixed essence in order to combat the perpetuation of rape myths and stereotypical ideas about women in general (Kiguwa, 2004). The shared assumptions and ideas regarding gender and sexuality mentioned above are one channel through which systems of patriarchy maintain structures of male domination. The present study has highlighted the subtle yet widespread existence of stereotypical beliefs about women who have been raped that both perpetuate gender inequality and the existence of rape myths.

The high incidence of rape in South Africa and an understaffed, overworked and underpaid police service serve to increase the likelihood of secondary victimisation. Policemen and women are exposed to extreme violence and life-threatening circumstances on a day-to-day basis, particularly in areas where crime levels are high (Pienaar \& Rothmann, 2005), such as the catchment area served by the TCC. The lack of vehicles, qualified officers and proper training makes them ill-equipped to deal with the staggering number of crimes of sexual assault that are reported to them (Pienaar \& Rothmann, 2005; Rasool et al., 2003). Moreover, police personnel seldom receive counselling or have access to support systems in order to adequately cope with the trauma-inducing nature of their jobs (Besdziek, 1999). The stressful nature of police work may contribute to difficulties in providing the best service possible to women reporting rape to the police.

\section{Further research}

It should be acknowledged that the findings of this study represent the subjective experiences of 16 women interviewed over the course of 2006. The small sample size and nature of the interview schedule allowed for the capturing and analysis of women's experiences, but limits the generalisability of the results. Future research may want to consider the experiences and subjective perceptions of police personnel in dealing with rape survivors in order to obtain a richer and textured understanding from the perspective of the SAPS.

Further research is also needed to follow women through the criminal justice system in a longitudinal study, focusing on relationships with investigating officers and prosecutors. A longitudinal study could reveal the incidence of self-blame and the internalisation of rape myths in women, and how the treatment of women throughout the court proceedings and the outcome of the case impacts upon the psychological recovery of rape survivors.

\section{CONCLUDING COMMENTS}

At the time of the interviews, the role that the police had played in the participant's journey post rape was a negative one in 10 out of 16 cases. The police service, as an institution, is an organisation of social control and power. The women who took part in the present study are marginalised on the basis of gender, class, race and relationship status. They seldom had access to the resources that would enable them to protect themselves, such as safe housing and reliable and safe transport, which arguably made them more vulnerable to rape (Boonzaier, 2003). When their bodies were violated, they chose to turn to the police for protection and some form of retribution. In the current study 10 out of the 16 women felt that the police had failed to provide them with the protection they had hoped for from the police service. 
Not only are attitudes towards rape related to occupational understandings and beliefs with regards to the police work, but they are also deeply embedded in gender relations within society. Police attitudes towards women who have been raped mirror the beliefs and attitudes of the wider society. "Social change can be achieved only when women are able to question the structures and institutions in their society that sustain oppression" (Kiguwa, 2004:291-292). In the light of the above quotation, perhaps the most important conclusion to emerge from the current study is that the findings echo those of Stanton et al. (1997) and Combrink and Skepu (2003). That is to say that 10 years on little seems to have changed on the ground with regards to the rape survivors' experience of reporting, despite a strong commitment evidenced by government to improve reporting services.

\section{REFERENCES}

ARTZ, L. 1999. Access to justice for rural women: special focus on violence against women. Cape Town: University of Cape Town, Institute of Criminology.

BESDZIEK, D. 1999. Options for city police services. Available: http://www. issafrica.org/Pubs/PAPERS/4/Paper4.html. [Retrieved: 29/01/2007].

BOONZAIER, F. 2003. Women abuse: a critical review. In: RATELE, K. \& DUNCAN, N. (eds) Social psychology: identities and relationships. Cape Town: University of Cape Town Press: 177-197.

BREMS, C. \& WAGNER, P. 1994. Blame of victim and perpetrator in rape versus theft. Journal of Social Psychology, 134(3):363-374.

BURGESS, A. \& HOLMSTROM, L. 1978. The victim of rape: institutional reactions. New York: Wiley.

BURT, M.R. 1980. Cultural myths and supports for rape. Journal of Personality and Social Psychology, 38(2):217-230.

BURT, M., \& ALBIN, R.S. 2006. Rape myths, rape definitions, and probability of conviction. Journal of Applied Social Psychology, 11:212-230.

CHIRORO, P., BOHNER, G., TENDAYI VIKI, G. \& JARVIS, C.I. 2004. Rape myth acceptance and rape proclivity. Journal of Interpersonal Violence, 19(4):427-442.

CHRISTOFIDES, N., WEBSTER, N., JEWKES, R., PENN-KEKANA, L., MARTIN, L. ABRAHAMS, N. \& KIM, J. 2003. The state of sexual assault services: findings from a situation analysis of services in South Africa. Technical report published by the South African Gender-based Violence and Health Initiative. Medical Research Council. Pretoria.

COOMBS, A.J. 1987. An evaluation of the changing perceptions and treatment of rape victims by the police. Brunel: Socio-legal Working Papers.

COMBRINCK, H. \& SKEPU, Z. 2003. Bail in sexual assault cases: victim's experiences. (No. 2). Cape Town: Gender Project, Community Law Centre.

GARTNER, R. \& MACMILLAN, R. 1995. The effect of the victim-offender relationship on reporting crimes of violence against women. Canadian Journal of Criminology, 37:393-429.

GAVEY, N. 2005. Just sex? The cultural scaffolding of rape. London: Routledge.

HERMAN, J.L 1992. Trauma and recovery. New York: Basic Books. 
INFORMATION MANAGEMENT- SOUTH AFRICAN POLICE SERVICES. (n.d.). Available: http://www.saps.gov.za/statistics/reports/crimestats/2006/crimestats/2006/crime stats.htm. [Retrieved: 26/02/2006].

JEWKES, R. \& ABRAHAMS, N. 2002. The epidemiology of rape and sexual coersion in South Africa: an overview. Social Science and Medicine, 55(7):1231-1244.

JEWKES, R., PENN-KEKANA, L., LEVIN, J., RATSAKA, M. \& SCHRIEBER, M. 2001. Prevalence of emotional, physical and sexual abuse of women in 3 South African provinces. South African Medical Journal, 91(5):421-428.

JORDAN, J. 2001. Worlds Apart? Women, rape and the police reporting process. British Journal of Criminology, 41(4):679-706.

JORDAN, J. 2002. Will any women do? Police, gender and rape victims. Policing, 25(2):319344.

KIGUWA, P. 2004. Feminist critical psychology in South Africa. In: HOOK, D. Critical psychology. Cape Town: University of Cape Town Press.

KOSS, M.P. \& HARVEY, M.R. 1991. The rape victim: clinical and community interventions $\left(2^{\text {nd }}\right.$ ed). California: Sage Publications.

KOSS, M.P., HEISE, L. \& RUSSO, N.F. 1994. The global health burden of rape. Psychology of Women Quarterly, 18:509-537.

LIRA, L.R., KOSS, M. \& RUSSO, N.F. 1999. Mexican American women's definitions of rape and sexual abuse. Hispanic Journal of Behavioral Sciences, 21(3):235-236.

MADIGAN, L. \& GAMBLE, N.C. 1991. The second rape: society's continual betrayal of the victim. New York: Lexington Books.

PIDGEON, N. \& HENWOOD, K. 1997. Using grounded theory in psychological research. In: HAYES, N. (ed) Doing qualitative analysis in psychology. Hove, UK: Psychology Press: 245-273.

PIENAAR, J. \& ROTHMANN, S. 2005. Suicide ideation in the South African Police Service. South African Journal of Psychology, 35(1):58-72.

PINO, N.W. \& MEIER, R.F. 1999. Gender differences in reporting rape. Sex Roles, 40(11/12):979-990.

PRETORIUS, Z. \& LOUW, B. 2005. Women and men as vulnerable victims. In: DAVIS, L. \& SNYMAN, R. (eds) Victimology in South Africa. Pretoria: Van Schaik Publishers.

RASOOL, S., VERMAAK, K., PHAROAH, R., LOUW, A. \& STAVROU, A. 2003. Violence against women: a national survey. Pretoria: Institute for Security Studies.

SMYTHE, D. 2004. The problem of attrition in rape cases. In: KARTH, V. (ed) News and views for magistrates. Cape Town: The Law, Race and Gender Research Unit.

SNYMAN, R. 2005. Overview of and concepts of victimology. In: DAVIS, L. \& SNYMAN, R. (eds) Victimology in South Africa. Pretoria: Van Schaik Publishers.

STANTON, S., LOCHRENBERG, M. \& MUKASA, V. 1997. Improved justice for survivors of sexual violence? Adult experiences of the Wynberg Sexual Offences Court and associated services. Rape Crisis: Cape Town; African Gender Institute: University of Cape Town; Human Rights Commission. 
STATISTICS SOUTH AFRICA. 2000. Victims of crime survey. Pretoria: Statistics South Africa.

STEPHANUS, F. 2006. The relationship between sex role orientation and rape victims blame among police officers in the Cape Peninsula. University of the Western Cape: Department of Psychology. (Unpublished minor dissertation for the MA Degree (Psychology))

STRAUSS, A. \& CORBIN, J. 1990. Basics of qualitative research: grounded theory procedures and techniques. London: Sage Publications.

SWANSON, J.M. 1986. Analyzing data for categories and description. In: CHEWITZ, W.C. \& SWANSON, J.M. (eds) From practice to grounded theory: qualitative research in nursing Menlo Park, CA: Addison Wesley: 121-132.

TEMKIN, J. 1997. Plus CA change: reporting rape in the 1990's. The British Journal of Criminology, 37(4):507-528.

TEMKIN, J. 1999. Reporting rape in London: a qualitative study. The Howard Journal, 38(1):17-41.

THOMPSON, M. 2000. Life after rape: a chance to speak? Sexual and Relationship Therapy, 15(4):325-343.

VETTON, L. 1999. Influence of gender on research: a critique of two victim surveys. Center for the Study of Violence and Reconciliation. Available: http://www.crvr.org. za/articles/artec1.htm. [Retrieved: 15/11/2006].

WALKLATE, S. 1995. Gender and crime. London: Willan Publishing.

WARD, C.A. 1995. Attitudes towards rape: feminist and social psychological perspectives. London: Sage Publications.

WESTHEIMER, R.K. \& LOPATER, S. 2005. Human sexuality: a psychosocial perspective. Baltimore: Lippincott Williams \& Wilkins.

WILLIAMS, L.S. 1984. The classic rape: when do victims report? Social Problems, 31(4):459-467.

Ms Nina du Plessis and Prof Ashraf Kagee, Department of Psychology, Stellenbosch University, Stellenbosch, South Africa.

Ms Anastasia Maw, Department of Psychology, University of Cape Town, Cape Town, South Africa. 